\title{
The Consequences of Mutations in the Reproductive Endocrine System
}

\author{
Donchan $\mathrm{Choi}^{\dagger}$ \\ Dept. of Life Science, College of Environmental Sciences, Yong-In University, Yongin 449-714, Korea
}

\begin{abstract}
The reproductive activity in male mammals is well known to be regulated by the hypothalamuspituitary-gonad axis. The hypothalamic neurons secreting gonadotropin releasing hormone $(\mathrm{GnRH})$ govern the reproductive neuroendocrine system by integrating all the exogenous information impinging on themselves. The GnRH synthesized and released from the hypothalamus arrives at the anterior pituitary through the portal vessels, provoking the production of the gonadotropins(follicle-stimulating hormone (FSH) and luteinizing hormone ( $\mathrm{LH})$ ) at the same time. The gonadotropins affect the gonads to promote spermatogenesis and to secret testosterone. Testosterone acts on the GnRH neurons by a feedback loop through the circulatory system, resulting in the balance of all the hormones by regulating reproductive activities. These hormones exert their effects by acting on their own receptors, which are included in the signal transduction pathways as well. Unexpected aberrants are arised during this course of action of each hormone. This review summarizes these abnormal phenomena, including various mutations of molecules and their actions related to the reproductive function.
\end{abstract}

Key words : Reproduction, Hypothalamus-pituitary-gonad axis, Mutation, Mammal

The reproductive endocrine system of male mammals is composed of the hypothalamus of the cerebrum, pituitary, and gonads. The hypothalamus integrates all the information for exogenous and endogenous signals to synthesize and secret gonadotropin-releasing hormone $(\mathrm{GnRH})$, regulating reproductive activities (Bliss et al., 2010). Thus GnRH is a decisive element that is the most important and supreme position in governing reproduction. Once GnRH is released, it is transported to the anterior pituitary. The nucleus of the GnRH neuronal cell is placed in the hypothalamus of the brain, and the axonal terminals of the GnRH neuronal cells is positioned at the median eminence (ME). The hypothalamo-hypophyseal portal blood vessels are found and these vessels take the substances secreted from the axonal terminals and transfer them to the anterior pituitary. the GnRH synthesized in the cell bodies of GnRH neurons is transported via the GnRH axons and

\footnotetext{
${ }^{4}$ Corresponding author: Donchan Choi, Dept. Life Science, College of Environmental Sciences, Yong-In University, Yongin 449-714, Korea. Phone: +82-31-8020-2781, Fax: +82-31-8020-2886, E-mail: dcchoi@yongin.ac.kr
}

released from the ME which is the sites of the axonal terminals of the GnRH neurons. Thereafter GnRH arrives at the anterior pituitary through the portal vessels. The gonadotropes in the anterior pituitary have receptors for the GnRH in their cell membranes so that the receptors can recognize and bind to the GnRH that flowed out of the portal vessels and the binding signals are delivered to the inside of the gonadotropes. These gonadotropes produce simultaneously follicle-stimulating hormone (FSH) and luteinizing hormone (LH) according to the GnRH signals. The gonadotropins (FSH and $\mathrm{LH}$ ) are released, moved through the systemic circulatory system, and act on the receptors of the target cells. In case of males, FSH is involved in the formation of spermatogenesis by acting on the seminiferous tubules of the gonads, and LH leads to produce testosterone that is the male sex steroid hormone, by acting on the Leydig cells that are located between the seminiferous tubules. Testosterone also travels through the circulatory system and acts on the hypothalamus/pituitary by negative feedback to maintain the constant levels of gonadotropins all the time, possessing the active sexual functions. In 
case of females, FSH promotes the maturation of ovarian eggs by acting on the follicles of the ovaries, while simultaneously leading the production of the female sex steroid estrogen. LH induces ovulation to facilitate the fertilization. Overall, this reproductive endocrine system is controlled via the hypothalamus-pituitary-gonad axis. As known from the reproductive endocrine circuit, typical and active reproductive functions are rational when $\mathrm{GnRH}, \mathrm{GnRH}$ receptors, two kinds of gonadotropins, and their receptors work suitably all together. Although there are other elements affecting the reproductive activity, the components mentioned above are of most importance.

Cells receive various exogenous signals and transport them inside themselves to exert their effects. This biochemical pathway is called the signal transduction system. Cells would produce unique substances matching the exogenous signals, and also regulate metabolism occurring inside the cells. In fact, if there are any dysfunctions in this pathway, various diseases such as cancer, immune- related symptoms, and neuronal disorder are susceptible. Therefore, the signal transduction system is clinically very important.

This review is to define the influence of the mutation developed due to the aberration of genes on the reproductive function, in relation to the molecules that act on the hypothalamus-pituitary gonad axis. In both human beings and animals, males are a major subject to this investigation, and females are involved, if necessary. In order to clarify the roles of the molecules more precisely, in case, genetically modified animal models are included.

\section{Hypothalamus-Pituitary Realm}

The reproductive endocrine system is activated by the $\mathrm{GnRH}$ released in a pulsatile fashion from the hypothalamus. The GnRH neurohormone binds to its receptor on the cell membrane of gonadotropes situated in the anterior pituitary. Then the gonadotropes synthesize and secret FSH and LH at the same time. The aberrant molecules in this course give a vital impact on the reproductive activity.

The congenital idiopathic hypogonadotropic hypogonadism (IHH) is a disorder that is immature and incomplete symptom in spite of age of 18. People suffering from this disease show low levels of blood gonadotropins and testosterone.

The IHH appeared to be resulted by any defects in the process of synthesis, release, and action of GnRH (Huhtaniemi, 2000). The symptom is developed with various correlations of other functions unrelated to the reproductive function, such as anosmia lacking smells, cleft palate rupturing the roofs of mouths, and sensorineural hearing losses. The IHH is classified as Kallman's syndrome when it is related to anosmia. This symptom is due to the improper movement of the GnRH neuronal cells from the olfactory epithelial cells to the hypothalamus during the development of the embryo (Franco et al., 1991; Hardelin et al., 1999). The more serious case is correlated to the $\mathrm{X}$ chromosome where the mutation directs a loss of the functioning of the KAL-1 gene encoding protein anosmin-1 (Franco et al., 1991). When the olfactory function is working normally it is named the normosmic IHH. The genes included in the cause of IHH are numerous, such as KAL1 (Franco et al., 1991; Legouis et al., 1991), FGFR1 (Dodé et al., 2003), GnRH (de Roux et al., 1997; Layman et al., 1998), NELF (Miura et al., 2004), GPR54 (Bedecarrats et al., 2003b; Seminara et al. 2003), FGF8, PROK2, and PROK2R (Hardelin \& Dodé, 2008). Recently, additional genes affecting the release of GnRH, containing GPR54/KISSIR, TAC3, and $T A C R 3$, are added to the list of causes of IHH (de Roux et al., 2003; Hardelin \& Dodé, 2008; Semple \& Topaloglu, 2010). By working alone or in combinations of genes, the genes prevent $\mathrm{GnRH}$ from functioning normally. The specific treatments administering GnRH 
and gonadotropins in the pulsatile usually recover the puberty, and restore the reproductive function to its normal state. In order for the people suffering from the IHH to maintain reproductive activity and secondary sex characteristics, it has been known that hormone treatment for a lifetime is required. However, one report shows that testes can function normally even after pausing the hormone treatment after a given period of time (Raivio et al., 2007).

The GnRH signals are not delivered intact when there is an aberrancy in the GnRH receptor anchoring on the cell membranes of gonadotropes in the anterior pituitary, even though GnRH is produced and released under normal conditions. In addition, it is also important that gonadotropes produce FSH and LH accurately.

\section{Defects of $\mathrm{GnRH}$}

$\mathrm{GnRH}$ is secreted from the hypothalamus in a fashion of pulse (Belchetz et al., 1978; Marshall \& Kelch, 1986; Tsutsumi \& Webster, 2009). Although exogenous GnRH is administered continuously into animals whose hypothalami containing GnRH neurons are surgically destroyed, the IHH is not cured without the increase of gonadotropins. Yet the pulsatile administration of $\mathrm{GnRH}$ in an interval of one hour showed normal spermatogenesis as a result of recovery of gonadal functioning (Belchetz et al., 1978). This emphasizes the critical actions of the pulsatile GnRH.

The GnRH is not produced from an animal that has a deletion mutation of the gene producing GnRH, If any GnRH produced, leading to IHH by the lack of function (Mason et al., 1986a). This mouse does not undergo puberty, and hypogonadotropic hypogonadism $(\mathrm{HH})$ continues, but the phenomenon might be recovered by proper administration of GnRH (Mason et al., 1986b). In case of the surgical amputation between the connection of the hypothalamus and the pituitary, IHH is induced secondarily by an abrupt decrease of gonadotropins (Clarke et al., 1983; Clarke \& Cimmins, 1984).

There is a report of insertion mutation where an adenine is added between adenine 18 and cytosine 19 of a gene generating GnRH (18insA); the latter is followed by the former (Bouligand et al., 2009). This mutated gene produces different amino acids composing GnRH, ultimately the amino acid sequence with the intact function is not formed. Since amino acids in GnRH is replaced by different amino acids in this 18insA mutation, GnRH ends up as a different peptide. The loss of function mutation in which a single base is inserted into the GnRH gene gives rise to IHH.

\section{Defects of $\mathrm{GnRH}$ receptors}

The GnRH receptor (GnRHR) is a member of $G$ protein-coupled receptor family and consists of 324 amino acids. This receptor is primarily expressed in the gonadotropes and even in the breast, gonads, prostate, and uterus in animals, including human beings (Cheung $\&$ Wong, 2008). GnRH receptor mutations occurr naturally and induce IHH (de Roux et al., 1997; Beranova et al., 2001; Bedecarrats et al., 2003a, 2003b; Wolczynski et al., 2003; Bedecarrats \& Kaiser, 2007; Fichna et al., 2011). There are several sites in the GnRH receptor gene where mutations happen. A mutation was reported that the amino acid 139 arginine in GnRHR was replaced by histidine (Arg139His) due to the alteration of guanine to adenine in position 416 of exon 1 of the GnRHR gene (Fichna et al., 2011). The mutation occurred in that place of the GnRHR gene was discovered before (Costa et al., 2001; Wołczynski et al., 2003; Topaloglu et al., 2006). In the results of in vitro experiments using the mutated GnRH receptor gene, the receptor mutants are normally expressed and inserted into the cell membrane. Yet the receptor mutants do not respond to GnRH. It could be speculated that the mutants of the GnRHR gene perhaps do not bind to GnRH or do not transport the signals inside the cell. Thus it is a reasonable conjecture that the mutation site would play an important role in transducing signals. Other mutants were discovered where amino acids of the GnRH receptor are altered. They are 
Thr32Ile, Cys200Tyr, Leu266Arg, and Cys279Tyr, in the order of the amino acids of the GnRH receptor (Beranova et al., 2001; Bedecarrats et al., 2003a). The sites that these mutations occupy in the GnRHR, in an order, the extracellular N-terminal domain, the secondary extracellular loop, the third intracellular loop, and the sixth transmembrane domain. All the mutant receptors are expressed and implanted on the surface of the cell membrane while the Cys200Tyr mutation is slightly reduced. The binding affinity is decreased in the Thr32Ile mutation, but it lacks in the rest of them. Thus signal transduction is not processed and even administration of the GnRH sustains the infertily state without an increase of the levels of gonadotropins.

Therefore, it is thought that IHH with mutation of the GnRH receptor gene is caused not to form the intact stereo-structure of molecules involved, not to insert in the cell membrane, not to uniformly relay the signals inside the cell, or the collapse of the molecules (Schubert et al., 2000; Petaja-Repo et al., 2001; LeanosMiranda et al., 2002).

\section{Pituitary-Gonad Realm}

Gonadotropins are FSH and LH released from the anterior pituitary and belong to the glycoprotein family. They are consisted of two subunits, having an $\alpha$ subunit in common, and a unique $\beta$ subunit. This $\alpha \beta$ dimer contains some carbohydrates.

Gonadotropins act in the form of an $\alpha \beta$ dimer on the cells anchoring their receptors. In males, FSH binds to the receptors on the surface of the Sertoli cell within the seminiferous tubule of the gonad, in association with testosterone, and promotes proliferation of spermatogonia and development of germ cells during and after meiosis. LH leads to production of testosterone by acting on the Leydig cells between the seminiferous tubules, and at the same time induces the synthesis of androgen-binding protein by acting on the Sertoli cells within the seminiferous tubules. In females, FSH binds to the receptors on the surfaces of the granulosa cells in the ovary, and stimulates the expression of an enzyme aromatase that converts androgen to estradiol. LH promotes the production of androgen in the follicular cells surrounding the egg during maturation. $\mathrm{LH}$ in the phase of completion of egg maturation causes granular somatic cells surrounding the egg to produce progesterone and induce ovulation. As the mutations in the gonadotropins and their receptors are very rare, they influence serious pregnant capacities. Yet, some mutations are sporadically found in the subunits of the hormones and their receptors. The heterozygous mutations exert their effects greatly on their fertilizing capacities. The receptors for gonadotropins are $\mathrm{G}$ protein-coupled glycoproteins, which cross the cell membrane seven times. FSH receptors consist of 10 exons and LHR 11 exons.

If the receptors for the gonadotropins FSH and $\mathrm{LH}$ are mutated, the consequences result in inactivation from the aberrant functioning out of the standard, the activation elevated twice, or complete inactivation. The mutation of FSHR sustains the activations constantly or inactivates completely (Themmen \& Huhtaniemi, 2000). This loss of function mutation of FSHR makes the small testes, which are not typical in males, and reduces estrogen production without matured follicles. The continuously activated FSHR makes testes large by increasing the Sertoli cells within the gonads (Simoni et al., 1997; Simoni et al., 1999). In females with the same phenomenon, the follicular cells grow excessively, cause the ovarian tumor, increase the incidence of fraternal twins, and undergo premature menopause (Ligtenberg et al., 1999). If the LHR holds its continuously activated situation, it ultimately provokes the same results as the process that the gonadotropins act, by being capable of transducing signals even in the absence of the LH hormone signals. The perfect inactivating mutations show the adverse effects and vanish or diminish the actions of the hormones. Also, by different 
quantitative effects of the hormones, the influence of the hormones can be emerged partially or not at all.

\section{Defects of $\alpha$ subunit common to gonadotropins}

A mutation was reported in a human being where glutamine 56 was replaced by alanine (Glu56Ala) in $\alpha$ subunit common to the gonadotropins (Nishimura et al., 1986). This mutated protein is significantly bigger than the normal protein that it is not possible to cooperate to $\beta$ subunit to form a dimer. Thus there is no sound stereostructure, no formation of a dimer, and no configuration of the glycosylation in this mutant. This mutant affects the gonadotropins, thyroid stimulating hormone, and even human chorionic gonadotropins. It does not form intact germ cells so that the individual turns out infertility.

\section{2. $\mathrm{FSH} \beta$ and defects of $\mathrm{FSH}$ receptors}

There is a report that observes the complete inactivation of the mutant occurred in the FSH $\beta$ subunit gene in both males and females (Berger et al., 2005). In males, puberty arrived normally but FSH was not detected at the level of the standard. The mutant showed a male with azoospermia while the LH and testosterone levels were acting normally (Lindstedt et al., 1998). In females, there were the infertile state, the primary amenorhhea, and the absence of telarche.

The alteration of thymine to cytosine in a nucleotide of the FSH $\beta$ gene guides the protein to mutate with Cys82Arg. Because of the disappearance of cysteine in the protein, it is speculated that FSH $\beta$ does not have the disulfide bond necessary to form a proper stereostructure, directing to a dysfunction. In other cases, men with the same symptoms mentioned above exhibited the onset of puberty delayed, gonads with small size, azoospermia, and low blood concentration of FSH (Phillip et al., 1998). There were mutations where two bases were deleted in the $\mathrm{FSH} \beta$ gene. In this mutation, amino acids at position $61-81$ in the $\mathrm{FSH} \beta$ chain were altered into entirely different amino acids and led to premature terminate codons, resulting in the amino acid position 87-111 not being translated. Since the end part of this $\operatorname{FSH} \beta$ mutant protein is cut, it can not form a dimer with $\alpha$ subunit. Therefore, this mutant conducts infertility without the reproductive function.

Also, in the case of females, there is a report of an individual who suffers from the primary amenorrhoea, the absence of telarche, and the infertility by deletion of two bases in the FSH $\beta$ subunit gene (Matthews et al., 1993; Matthews \& Chatterjee, 1997). The mutant, too, produces a short $\operatorname{FSH} \beta$ chain in length as mentioned above. The mutant has no function due to the incapability of formation of a dimer. Yet when the FSH protein is administered to the mutant, follicle maturation, ovulation, and pregnancy are brought about. Another case that was reported was dual mutants in the $\mathrm{FSH} \beta$ gene as well (Layman et al., 1997). One is identical to the aforementioned case and the other is a missence mutation, in which the thymine was altered into guanine to form Cys51Gly. Normal FSH was not generated from cells transfected by the FSH $\beta$ mutant, and FSH hormone was not released by the deletion of cysteine in constructing the three dimensional structure of the FSH protein.

In other FSHR mutations occurred in males, amino acid 189 alanine is replaced by valine (Ala189Val), but muscularization and testosterone concentrations are as usual; FSH and LH levels are slightly increased, and the size of testis is reduced by various degrees (Tapanainen et al., 1997). Yet, people who had this kind of mutation left offsprings, who are not serious aberrant happenings. The same incidents from males were reported. The woman with this mutation showed high levels of FSH and LH, but she suffered from the lack of secondary characteristics and the disorder of ovarian developments (Aittomäki et al., 1996). It is considered that this mutant protein might result in abnormality in the three dimensional structure, and might not enter the cell membrane, thus FSH signals 
might unable to be transduced.

The four kinds of mutations of FSHR expressed as the unusual situation were discovered in the course of the production of FSHR in females during the cure of infertility. It was identified that there were three kinds of deletions occurred in exons and one inserted intron in scrutinizing the FSHR mRNA (Gerasimova et al., 2010). In other words, the discoveries were deletion mutants of a single exon 2, 6, or 9, and the rest was an insertion mutant where 102 bases in intron 8 were duplicated. They were all heterozygotes possessing normal FSHR as well. All people showed only one single mutant. The nucleotides of exon 2,6 , or 9 are multiples of 3 , thus the sequence of amino acids expressed is not different from the intact sequence except for the parts deleted. All the mutations were arised from the extracellular $\mathrm{N}$-terminal domain of the receptor, then influenced the binding of the ligand. When the mutant gene was expressed in the eukaryotic cell line, the concentration of the cyclic adenosine monophosphate (cAMP) was distinctly reduced compared to the control with normal FSHR gene. Cells that hold the FSHR mutated do not respond to FSH, but cAMP levels would be normal if the forskolin that does not go through the receptor is treated. Thus the results indicate that mutations of FSHR appear to be some causes of innate sterility.

The other FSHR mutation is Asp224Val, which almost does not bind to FSH (exon 3, the third intracellular loop), and Leu601Val mutation (exon 10, the third intracellular loop) showed about $15 \%$ of the signal transduction function. Mutations that FSHR works somewhat less than the standard were also found, presenting the secondary amenorrhea and absence or weakening of the secondary follicle development (Beau et al 1998). These mutations are Ile160Thr (exon 6, extracellular domain) and Arg573Cys (exon 10, the third intracellular loop, resulting in abnormal expression on the cell membrane and deviant binding to the $\mathrm{G}$ protein.
The constantly activating FSHR mutation was also reported (Gromoll et al., 1996). When testosterone was administered to a male who took surgically out pituitary, the levels of gonadotropins were very low, but the spermatogenesis functioned as standard. This mutation is Asp567Gly (exon 10, the third intracellular loop), Asp564Gly mutation in LHR is always activated and exerts its effects.

\section{3. $\mathrm{LH} \beta$ and defects of $\mathrm{LH}$ receptors}

A male who had mutation in the LH $\beta$ gene did not undergo puberty normally even at the age of 17 (Weiss et al., 1992). Although the levels of testosterone in blood were low, the man responded normally to the administration of hCG. The blood levels of LH detected from this man had no biological activity. The man had 3 persons who were sterile among his relatives, thus it was regarded that he might have innate defects in the structure of LH. It turned out that he had a missense mutant altered from glutamine to arginine by anomaly changing adenine to guanine in the $\mathrm{LH} \beta$ gene 54 . His mother, sister, and maternal uncle were identified as heterozygote in the same site of the $\mathrm{LH} \beta$ gene. When this $\mathrm{LH} \beta$ gene mutant was expressed with a normal $\alpha$ subunit gene of the gonadotropin simultaneously in $\mathrm{CHO}$ (Chinese hamster ovary) cells, it was speculated that the LH $\alpha \beta$ dimers were formed, but could not bind to LH receptors by the absence of activation.

A mutation was found in a protein where three amino acids (amino acid 10 to 12; histone-proline-isoleucine) were lacked by deletion of nine nucleotides in exon 2 of the LH $\beta$ gene (Achard et al., 2009). This man did not show muscularizing effects, the concentration of LH was not detected, and the blood testosterone levels were low. Also, there were not many Leydig cells between the seminiferous tubules of the testis. Yet, he had intact spermatozoa, thus the process of spermatogenesis was thought unimpaired. It was concluded that the LH $\beta$ mutant protein was enough to proceed 
normal functions in the spermatogenesis because it showed some feasible functions in the in vitro experiment. One of this man's sisters presented identical symptoms of the mutation. That is, when the sister was 14 years old, she underwent menarche, oligomenorrhea, and secondary amenorrhea. When she grew-up, she demonstrated macrocysts in both ovaries. The levels of LH could not be detected, estradiol concentration was low, but FSH was elevated.

A mutation was reported where 2 sites in the $\operatorname{LH} \beta$ gene were altered (Arnhold et al., 2009). It was a mutant of both Trp8Arg (TGG $\rightarrow$ CGG) and Ile15Thr (ATC $\rightarrow$ ACC), occurring in the order of amino acids (Pettersson et al., 1994; Nilsson et al., 1998). The infertile women with the same mutation were successively recorded, in which the concentration of LH was not detected (Furui et al., 1994; Okuda et al., 1994).

Many mutations were emerged from the LHR gene, such as polymorphism without any functional changes, persistent activation, and chronic inactivation (Laue et al., 1995; Martens et al., 1998; Auger et al., 2008; Themmen \& Huhtaniemi, 2000). As soon as LHR is expressed as persistent activation mutants, the signal of LH is immediately transported to the target cells in the gonads. The influence begins early in life for boys, and directs to premature in the early periods of puberty unrelated to gonadotropins. These mutations were developed in the transmembrane domain of LHR. The sites were the sixth transmembrane helix, the third intracellular loop near it, and other transmembrane helices. The mutant LHR presented high levels of cyclic AMP (cAMP) by a factor of 5-15 without respect to LH (Shenker et al., 1993; Kraaij et al., 1995; Liu et al., 1999).

The mutation of LHR with chronic inactivation is pseudohermaphroditism, where the sex chromosomes turned out XY, but the affected person had female exterior genital organs (Themmen \& Huhtaniemi, 2000). The person had no uterus. It is because the Müllerian duct is degenerated by the correct action of the anti- Müllerian hormone (AMH) during the development process. Even though the Sertoli cells within the testis functioned normally, the Leydig cells underdeveloped (agenesis) completely. The inactivation of LHR becomes imperfect, and the muscularization seemingly develops poorly in various degrees from micropenis to hypospadias.

In females, the inactivation of LHR appeared to be anovulatory amenorrhea, primary and secondary sex characteristics developed normally, but the levels of FSH and LH were elevated, the concentrations of estrogen and progesterone were diminished. When the ovaries were analyzed by histological examinations, the follicles stayed at an immature phase, had no corpus luteum in ovaries, and showed no ovulation.

\section{Androgen and Defects of Androgen Receptors and Others}

Testosterone exerts its effects by way of the androgen receptor (AR) anchored on the cell membrane of the Leydig cells by LH. The AR belongs to nuclear receptor superfamily, and acts as a transcription factor that leads to the expression of genes in the target cells. Testosterone binds to its receptor to form dimers of the receptors, ultimately conducting the expression of the genes generating signals in the target cells. The mutations that do not draw the expressions of genes in the target cells are sterile in large, and give rise to genetic disorders such as androgen insensitivity syndrome (AIS) and testicular feminization (Tfm) (La Spada et al., 1991; Griffin, 1992; Quigley et al., 1995; McPhaul, 1999). The affected person showed a variety of symptoms from the feminization of genital organs and the absence of puberty to meager disorders (some fertiles), while similar symptoms were reported in animals such as mice and rats (Bardin et al., 1970; Lyon \& Hawkes, 1970; Goldstein \& Wilson, 1972; Giwercman et al., 2000; Chu et al., 2002). Another mutation was recorded where 840 amino acid arginine was changed to cysteine by the replacement of cytocine to thymine at 375 nucleotide in exon 7 of the AR gene. 
Family members who show these kinds of symptoms were mostly sterile, and some had the capability of pregnancy despite having the same characteristics. These consequences mean that there is another mechanism that is able to overcome this mutation. The Sertoli cells within the seminiferous tubule and the Leydig cells, functioning an important role in testis, present AR (Sar et al., 1990; Bremner et al., 1994; Vornberger et al., 1994). The knockout (loss of function of gene) male rats that lack the function of AR demonstrated very similar symptoms as seen in AIS and Tfm (Yeh et al., 2002; Matsumoto et al., 2003). The levels of gonadotropins in a man who had a mutant in AR were high and testosterone was normal. The person had a mutation in exon 1 of the AR gene, thus 240 amino acid alanine was replaced by serine (Ala240Ser), resulting in sterile (Goglia et al., 2011).

A mutation (Asn727Lys) occurring in the AR-ligand binding domain impairs the spermatogenesis seriously, leading to infertile (Yong et al., 1994). In this case, cytocine was replaced by guanine, guiding the alteration of asparagine to lysine at the 727 amino acid in AR (Lim et al., 2000). The mutated site was located between the third and the fourth of ligand-binding domains, if treated with androgen analog mesterolone (1 $\alpha$-methylDHT, $1 \alpha$-methyl-17 $\beta$ hydroxy-5 $\alpha$-androstan-3-one), pregnancy could be performed by producing normal spermatozoa. When the treatment of mesterolone stops, the production of spermatozoa is lacked, thus the AR mutations are known to be regulated by administrations of the proper drugs.

The sterile individual was emerged by impairment of spermatogenesis, in case that substituted methionine with valine, due to a mutation of altering adenine to guanine in 886 nucleotide in exon 8 of the AR gene. This substitution resulted in the AR-ligand binding domain as usual, the binding was not an aberrant binding, thus it was speculated that an unusual process was emerged in the signal transduction pathway which is aided by the assistant factors (Ghadessy et al., 1999). More results similar to the consequences mentioned above were already recorded (Yong et al., 1994; Berrevoets et al., 1998; Wang et al., 1998). The administration of androgen to a mouse who did not produce gonadotropins normalized the spermatogenesis, but the FSH treatment did not recover the spermatogenesis perfectly (Singh \& Handelsman, 1996; Haywood et al., 2003). Thus, in order for the androgen and its receptor to generate mature spermatozoa, both should work in the normal fashion, indicating the decisive evidence of reproductive activity.

If the Sertoli cells in the seminiferous tubule have no AR, the first meiosis in the spermatogenesis does not go over to the next step. If the Leydig cells have no $\mathrm{AR}$, the steroid hormone does not exert its effects, directing a pause in the spermatogenesis in the phase of round spermatid formation (Wang et al., 2009).

A mouse that does not express kisspeptin or its receptors presents $\mathrm{HH}$ and becomes infertile. When the kisspeptin is exogenously administered to a mouse without expression of kisspeptin, spermatogenesis is recovered partly. Yet, the mouse who does not express kisspeptin receptors does not respond to the treatment of kisspeptin (Berger et al., 2005). The mouse who does not express the estrogen receptor $\alpha$ becomes sterile, and does not respond to estrogen as well. While the mouse who does not express ER $\beta$ showed an impairment in the capacity of ovulation, but the mouse does respond to exogenous estrogen (Wintermantel et al., 2006). Besides the results inscribed above, there are a great deal of mutations inducing sterility (Romero et al., 2011).

\section{Transgenic Animals}

Many experiments apply the alteration of a particular part of a gene to produce functional modifications. There were reports that mutations were occurred in the $\alpha$ subunit common to genadotropins and in the unique 
FSH $\beta$ subunit in mice (Kendall et al., 1994; Kumar et al., 1997). As expected, mutations that vanished the function of the $\alpha$ subunit gene appeared as a dwarf due to the IHH and the hypothyroidism. The thyroid underdeveloped at the later period of pregnancy in the mouse, and the development of gonads was inhibited several weeks after birth. However, steps involved in the movement of the GnRH neuronal cells, the development of organs related to sex, and the gonadal growth appeared to be normal.

Although the small testes and the impaired spermatogenesis were observed in the knockout male mouse whose FSH $\beta$ gene was inactivated, the mouse became muscularized and fertile (Kumar et al., 1997). This mutation was quite similar to the FSHR knockout male mouse and men with persistently inactivated mutations (Tapanainen et al., 1997; Dierich et al., 1998; Abel et al., 2000). In results, FSH is required for the normal size of gonads and the qualitative aspects of typical spermatogenesis, but has less importance for the spermatogenesis itself and reproductive functioning of males.

The FSH $\beta$ knockout female mouse is infertile because the formation of follicles is paused before the growth of the secondary follicles (Kumar et al., 1997). This incidence is analogous to the mutations occurred in the FSH $\beta$ and FSHR of human beings (Aittomaki et al., 1995). The FSHR knockout results in mice are considerably similar as well (Dierich et al., 1998; Abel et al., 2000). All the females are sterile, the ovaries are small and attenuated, the corpus lutea are absent, and even the oogenesis presents not to proceed until the secondary follicular maturation.

The transgenic male mouse with overexpression of FSH exhibited normal differentiation of gonads and spermatozoa formation (Kumar et al., 1999). Yet, the mouse was sterile because of the potential abnormal behavior, defective spermatozoa, or imperfect semen. The levels of testosterone were high, and seminal vesicles were enlarged in the mouse. The elevated FSH concentration seemed to somehow stimulate the Leydig cells. A man whose pituitary adenoma secreted a large amount of FSH showed abnormal testicles (Galway et al., 1990).

The female mouse overexpressed FSH was sterile, the mouse presented cystic ovary, and the levels of blood testosterone, estradiol, and progesterone were increased (Kumar et al., 1999). It was found that FSH alone does not induce tumor because no ovarian tumors were discovered. Thus it is speculated that the sterile situation was caused by anomalous oogenesis and the formation of ovarian cysts.

If the $\mathrm{LH} \beta$ subunit gene or the LH receptor gene is removed from the mouse, the sterile state is induced in both sexes, steroid hormone is produced less in testicles of males, release of the hormone is also diminished, thus spermatogenesis in males is defected and the follicular maturation in females is paused (Lei et al., 2001; Zhang et al., 2001). The defects of the FSH receptor in males seriously impair the testicular function and lead to the reduction of numbers of the Leydig cells and the decrease of testosterone (Baker et al., 2003). As the concentration of FSH is normal in the animal, the exogenous LH can overcome IHH in the absence of the LH $\beta$ subunit (Kumar et al., 1997). Similarly, a female mouse also becomes infertile by pausing the follicular maturation if defects exist in the FSH receptor (Dierich et al., 1998; Abel et al., 2000). The levels of LH appeared to be not high in the male mouse overexpressed $\mathrm{LH}$, but the LH levels were elevated in the female overexpressed LH (Risma et al., 1995). This female was sterile with almost no ovulation, showed a delayed period of the corpus luteum, and developed swollen cysts and pathological ovarian diseases like tumor in the granulosa cells and the theca interna cells. Moreover, the adrenal glands were abnormal in some animals. Therefore, the persistently high levels of LH correlate to ovarian tumor, and to some degrees, the polycystic ovary syndrome (PCOS) in humans as well. As mentioned above, the action of the gonadotropin has been found 
in a knockout model of the $\alpha$ and $\operatorname{FSH} \beta$ subunits. Experimental results that the function of the FSHR gene was altered were reported (Dierich et al., 1998; Abel et al., 2000). The mouse whose $\mathrm{LH} \beta$ subunit is not expressed survives, but becomes sterile since the loss of the gonadal growth. The testicles in these mice are small, the Leydig cells are not differentiated, and the blood testosterone levels were low. The spermatogenesis of the mice does not proceed to elongated spermatids by ceasing the stage of round spermatid. There are small ovaries in females and decreased levels of estradiol and progesterone in blood. The oogenesis is not normal, the follicles are not matured, thus the corpus lutea are not observed at all. The abnormal symptoms were recovered when the mouse was administered by sufficient hCG that is similar to $\mathrm{LH}$ in the structural aspect, so the responsiveness of the $\mathrm{LH}$ target cells appeared to be normal. Thus it would be a good model to investigate the effects of the absence of $\mathrm{LH}$, provided that the responsiveness of LH in the target cells is ordinary in the knockout animal where the $\mathrm{LH} \beta$ gene is not expressed (Kumar, 2007; Ma et al., 2004).

The male mouse with the loss of function of FSHR is fertile, has small testes, and shows low concentration of testosterone. The number of quite active spermatozoa is small and the portions of abnormal spermatozoa are increased. The decrease of testis in size is due to the reduction of the volume of the seminiferous tubule. The pituitary was enlarged by the increase of FSH concentrations 2-3 times and the number of the cells producing FSH was increased. In many aspects, the mouse whose function of FSH is deficient showed a similar phenomenon in the inactivated person by the mutation occurred on the activity of FSHR (Aittomäki et al., 1995, 1996; Tapanainen et al., 1997). In other words, the number of abnormal spermatozoa is great but the spermatogenesis was not arrested completely, and the follicular development in females was inhibited whereas the primary follicles remained intact. The female mouse with the loss of function of FSHR by replacing exon 1 of FSHR with a marker gene was found sterile, had high levels of FSH concentration, had the small ovaries, had the low levels of estrogen, the inhibited follicular development and thin womb, and exhibited no matured follicle and no corpus lutea (Dierich et al., 1998). The mutants discovered in the FSHR of women are Asn680Ser, Ala189Val, Ile160Thr, and Thr449Ile (Binder et al., 2012). They can not exert the reproductive function themselves but are capable of causing pregnancy by various aids. Namely, it means that the reproductive capacity is not entirely disappeared in the mutations of FSHR.

\section{CONCLUSION}

By applying the molecular biology method, the structure and function of genes have been well-known. The reproductive endocrine system regulates the gonadal functions through the hypothalamus and the pituitary in orderly fashion. The critical elements involved in the hypothalamus-pituitary-gonad axis are GnRH and its receptors, gonadotropins and their receptors. Also, the reproductive activity is maintained perfectly if all the signal transduction mechanisms in the testis and ovary work normally. With investigating the aberrant situation of genes that produce proteins related to the reproduction, a better healing power would be provided by right diagnosis about the aberrant diseases of the reproductive function.

Gonadotropins and their receptor polymorphism are discovered, but their impacts on the pituitary-gonad axis have not been scrutinized in large. The constantly activated LHR, as seen in the Leydig cell adenoma, induces tumor with extraordinary high levels of gonadotropin action (Liu et al., 1999). Also, uniformly high concentrations of gonadotropins can cause tumor development in organs such as the adrenal glands by leading to express the gonadotropin receptors in other places than gonads. Yet, it has not been satisfactorily 
explained how the gonadotropin receptors are expressed in other tissues, except for the gonads (Rao, 1996). The knockout mouse of LHR would be helpful in solving this problem, and the animal models would be useful in studying the mutants of mRNA of gonadotropin receptors.

As the roles of the normal and abnormal gonadotropins are understood, new discoveries in the regulatory mechanism of the reproductive endocrine system are accomplished and announced. Not only the genetically modified animal models, but also the gonadotropins of human beings and the mutations and polymorphism of their genes will reveal fundamentally the action mechanism of reproductive endocrine system through the novel information in the area of the hormonal control regarding the reproductive functioning.

\section{REFERENCES}

Abel MH, Wootton AN, Wilkins V, Huhtaniemi I, Knight PG, Charlton HM (2000) The effect of a null mutation in the follicle-stimulating hormone receptor gene on mouse reproduction. Endocrinology 141:1795-1803. Achard C, Courtillot C, Lahuna O, Méduri G, Soufir $\mathrm{JC}$, Lière $\mathrm{P}$, Bachelot $\mathrm{A}$, Benyounes $\mathrm{H}$, Schumacher M, Kuttenn F, Touraine P, Misrahi M (2009) Normal spermatogenesis in a man with mutant luteinizing hormone. N Engl J Med 361:1856-1863.

Aittomäki K, Herva R, Stenman UH, Juntunen K, Ylöstalo P, Hovatta O, de la Chapelle A (1996) Clinical features of primary ovarian failure caused by a point mutation in the follicle-stimulating hormone receptor gene. J Clin Endocrinol Metab 81:3722-3726.

Aittomäki K, Lucena JL, Pakarinen P, Sistonen P, Tapanainen J, Gromoll J, Kaskikari R, Sankila EM, Lehväslaiho H, Engel AR, Nieschlag E, Huhtaniemi I, de la Chapelle A (1995) Mutation in the folliclestimulating hormone receptor gene causes hereditary hypergonadotropic ovarian failure. Cell 82:959-968.
Arnhold IJ, Lofrano-Porto A, Latronico AC (2009) Inactivating mutations of luteinizing hormone beta subunit or luteinizing hormone receptor cause oligoamenorrhea and infertility in women. Horm Res 71:75-82.

Auger J, Faugeron I, Larue L, Lumbroso S, Themmen APN, Bouchard P (2008) A new LH receptor splice mutation responsible for male hypogonadism with subnormal sperm production in the propositus, and infertility with regular cycles in an affected sister. Human Reprod 23:1917-1923.

Baker PJ, Pakarinen P, Huhtaniemi IT, Abel MH, Charlton HM, Kumar TR, O’Shaughnessy PJ (2003) Failure of normal Leydig cell development in follicle-stimulating hormone (FSH) receptor deficient mice, but not FSH beta-deficient mice: role for constitutive FSH receptor activity. Endocrinology 144:138-145.

Bardin CW, Bullock L, Schneider G, Allison JE, Stanley AJ (1970) Pseudohermaphrodite rat: end organ insensitivity to testosterone. Science 167:1136-1137.

Beau I, Tourraine P, Meduri G, Gougeon A, Desroches A, Matuchansky C, Milgrom E, Kuttenn F, Misrahi M (1998) A novel phenotype related to partial loss of function mutations of the follicle stimulating hormone receptor. J Clin Invest 102:1352-1359.

Bedecarrats GY, Kaiser UB (2007) Mutations in the human gonadotropin-releasing hormone receptor: insights into receptor biology and function. Semin Reprod Med 25:368-378.

Bedecarrats GY, Linher KD, Janovick JA, Beranova M, Kada F, Seminara SB, Michael CP, Kaiser UB (2003a) Four naturally occurring mutations in the human GnRH receptor affect ligand binding and receptor function. Mol Cell Endocrinol 205:51-64.

Bedecarrats GY, Linher KD, Kaiser UB (2003b) Two common naturally occurring mutations in the human gonadotropin-releasing hormone $(\mathrm{GnRH})$ receptor have differential effects on gonadotropin gene expression and on GnRH-mediated signal transduction. J Clin 
Endocrinol Metab 88:834-843.

Belchetz PE, Plant TM, Nakai Y, Keogh EJ, Knobil E

(1978) Hypophysial responses to continuous and intermittent delivery of hypopthalamic gonadotropinreleasing hormone. Science 202:631-633.

Beranova M, Oliveira LM, Bédécarrats GY, Schipani E, Vallejo M, Ammini AC, Quintos JB, Hall JE, Martin KA, Hayes FJ, Pitteloud N, Kaiser UB, Crowley WF Jr, Seminara SB (2001) Prevalence, phenotypic spectrum, and modes of inheritance of gonadotropin-releasing hormone receptor mutation in idiopathic hypogonadotropic hypogonadism. J Clin Endocrinol Metab 86:1580-1588.

Berger K, Souza H, Brito VN, d'Alva CB, Mendonca BB, Latronico AC (2005) Clinical and hormonal features of selective follicle-stimulating hormone (FSH) deficiency due to FSH beta-subunit gene mutations in both sexes. Fertil Steril 83:466-470.

Berrevoets CA, Doesburg P, Steketee K, Trapman J, Brinkman AO (1998) Functional interactions of the AF-2 activation domain core region of the human androgen receptor with the amino-terminal domain and with the transcriptional coactivator TIF2 (transcriptional intermediary factor 2). Mol Endocrinol 12: 1172-1183.

Binder H, Strick R, Zaherdoust O, Dittrich R, Hamori M, Beckmann MW, Oppelt PG (2012) Assessment of FSHR variants and anti-Müllerian hormone in infertility patients with a reduced ovarian response to gonadotropin stimulation. Fertil Steril 97:11691175.

Bliss SP, Navratil AM, Xie J, Roberson MS (2010) GnRH signaling, the gonadotrope and endocrine control of fertility. Neuroendocrinology 31:322-340.

Bouligand J, Ghervan C, Tello JA, Brailly-Tabard S, Salenave S, Chanson P, Lombès M, Millar RP, Guiochon-Mantel A, Young J (2009) Isolated familial hypogonadotropic hypogonadism and a GnRH1 mutation. N Engl J Med 360:2742-2748.
Bremner WJ, Millar MR, Sharpe RM, Saunders PT (1994) Immunohistochemical localization of androgen receptors in the rat testis: evidence for stage-dependent expression and regulation by androgens. Endocrinology 135:1227-1234.

Cheung LW, Wong AS (2008) Gonadotropin-releasing hormone: GnRH receptor signaling in extrapituitary tissues. FEBS J 275:5479-5495.

Chu J, Zhang R, Zhao Z, Zou W, Han Y, Qi Q, Zhang H, Wang JC, Tao S, Liu X, Luo Z (2002) Male fertility is compatible with an Arg840Cys substitution in the AR in a large Chinese family affected with divergent phenotypes of AR insensitivity syndrome. Clin Endocrinol Metab 87:347-351.

Clarke IJ, Cummins JT (1984) Direct pituitary effects of estrogen and progesterone on gonadotropin secretion in the ovariectomized ewe. Neuroendocrinology 39: 267-274.

Clarke IJ, Cummins JT, de Kretser DM (1983) Pituitary gland function after disconnection from direct hypothalamic influences in the sheep. Neuroendocrinology 36:376-384.

Costa EM, Bedecarrats GY, Mendonca BB, Arnhold IJ, Kaiser UB, Latronico AC (2001) Two novel mutations in the gonadotropin-releasing hormone receptor gene in Brazilian patients with hypogonadotropic hypogonadism and normal olfaction. J Clin Endocrinol Metab 86: 2680-2686.

de Roux N, Genin E, Carel JC, Matsuda F, Chaussain JL, Milgrom E (2003) Hypogonadotropic hypogonadism due to loss of function of the KiSS1-derived peptide receptor GPR54. Proc Natl Acad Sci USA 100: 10972-10976.

de Roux N, Young J, Misrahi M, Genet R, Chanson P, Schaison G, Milgrom E (1997) A family with hypogonadotropic hypogonadism and mutations in the gonadotropin-releasing hormone receptor. N Engl J Med 337:1597-1602.

Dierich A, Sairam MR, Monaco L, Fimia GM, Gansmuller 
A, LeMeur M, Sassone-Corsi P (1998) Impairing follicle-stimulating hormone (FSH) signaling in vivo: targeted disruption of the FSH receptor leads to aberrant gametogenesis and hormonal imbalance. Proc Natl Acad Sci USA 95:13612-13617.

Dodé C, Levilliers J, Dupont JM, De Paepe A, Le Dû N, Soussi-Yanicostas N, Coimbra RS, Delmaghani S, Compain-Nouaille S, Baverel F, Pêcheux C, Le Tessier D, Cruaud C, Delpech M, Speleman F, Vermeulen S, Amalfitano A, Bachelot Y, Bouchard P, Cabrol S, Carel JC, Delemarre-van de Waal H, Goulet-Salmon B, Kottler ML, Richard O, SanchezFranco F, Saura R, Young J, Petit C, Hardelin JP (2003) Loss-of-function mutations in FGFR1 cause autosomal dominant Kallmann syndrome. Nat Genet 33:463-465.

Fichna P, Fichna M, Żurawek M, Nowak N (2011) Hypogonadotropic hypogonadism due to GnRH receptor mutation in a sibling. Pol J Endocrinol 62:264-267.

Franco B, Guioli S, Pragliola A, Incerti B, Bardoni B, Tonlorenzi R, Carrozzo R, Maestrini E, Pieretti M, Taillon-Miller P, Brown CJ, Willard HF, Lawrence C, Graziella Persico M, Camerino G, Ballabio A (1991) A gene deleted in Kallmann's syndrome shares homology with neural cell adhesion and axonal pathfinding molecules. Nature 353:529-536.

Furui K, Suganuma N, Tsukahara S, Asada Y, Kikkawa F, Tanaka M, Ozawa T, Tomoda Y (1994) Identification of two point mutations in the gene coding luteinizing hormone $(\mathrm{LH})$ beta-subunit, associated with immunologically anomalous LH variants. J Clin Endocrinol Metab 78:107-113.

Galway AB, Hsueh AJ, Daneshdoost L, Zhou MH, Pavlou SN, Snyder PJ (1990) Gonadotroph adenomas in men produce biologically active follicle stimulating hormone. J Clin Endocrinol Metab 71:907-912.

Gerasimova T, Thanasoula MN, Zattas D, Seli E, Sakkas $\mathrm{D}$, Lalioti MD (2010) Identification and in vitro characterization of follicle stimulating hormone (FSH) receptor variants associated with abnormal ovarian response to FSH. J Clin Endocrinol Metab 95:529536.

Ghadessy FJ, Lim J, Abdullah AAR, Panet-Raymond V, Choo CK, Lumbroso R, Tut TG, Gottlieb B, Pinsky L, Trifiro MA, Yong EL (1999) Oligospermic infertility associated with an androgen receptor mutation that disrupts interdomain and coactivator (TIF2) interactions. J Clin Invest 103:1517-1525.

Giwercman A, Kledal T, Schwartz M, Giwercman YL, Leffers H, Zazzi H, Wedell A, Skakkebaek NE (2000) Preserved male fertility despite decreased androgen sensitivity caused by a mutation in the ligand-binding domain of the androgen receptor gene. J Clin Endocrinol Metab 85:2253-2259.

Goglia U, Vinanzi C, Zuccarello D, Malpassi D, Ameri P, Casu M, Minuto F, Foresta C, Ferone D (2011) Identification of a novel mutation in exon 1 of androgen receptor gene in an azoospermic patient with mild androgen insensitivity syndrome: case report and literature review. Fertil Steril 2011 96: 1165-1169.

Goldstein JL, Wilson JD (1972) Studies on the pathogenesis of the pseudohermaphroditism in the mouse with testicular feminization. J Clin Invest 51:16471658 .

Griffin JE (1992) Androgen resistance-the clinical and molecular spectrum. N Engl J Med 326:611-618.

Gromoll J, Simoni M, Nieschlag E (1996) An activating mutation of the follicle-stimulating hormone receptor autonomously sustains spermatogenesis in a hypophysectomized man. J Clin Endocrinol Metab 81:13671370.

Hardelin JP, Dodé C (2008) The complex genetics of Kallman syndrome: KAL1, FGFR1, FGF8, PROKR2, PROK2, et al. Sex Dev 2:181-193.

Hardelin JP, Julliard AK, Moniot B, Soussi-Yanicostas N, Verney C, Chwanzel-Fukuda M, Ayer-Le Lievre C, Petit C (1999) Anosmin-1 is a regionally restricted 
component of basement membranes and interstitial matrices during organogenesis: implications for the developmental anomalies of $\mathrm{X}$ chromosome-linked Kallmann syndrome. Dev Dyn 215:26-44.

Haywood M, Spaliviero J, Jimemez M, King NJ, Handelsman DJ, Allan CM (2003) Sertoli and germ cell development in hypogonadal (hpg) mice expressing transgenic follicle-stimulating hormone alone or in combination with testosterone. Endocrinology 144:509517.

Huhtaniemi I (2000) Mutations of gonadotrophin and gonadotrophin receptor genes: what do they teach us about reproductive physiology? J Reprod Fertil 119:173-186.

Kendall SK, Gordon DF, Birkmeier TS, Petrey D, Sarapura VD, O'Shea KS, Wood WM, Lloyd RV, Ridgway EC, Camper SA (1994) Enhancer-mediated high level expression of mouse pituitary glycoprotein hormone alpha-subunit transgene in thyrotropes, gonadotropes, and developing pituitary gland. Mol Endocrinol 8:1420-1433.

Kraaij R, Post M, Kremer H, Milgrom E, Epping W, Brunner HG, Grootegoed JA Themmen AP (1995) A missense mutation in the second transmembrane segment of the luteinizing hormone receptor causes familial male-limited precocious puberty. J Clin Endocrinol Metab 80:3168-3172.

Kumar TR (2007) Functional analysis of LH beta knockout mice. Mol Cell Endocrinol 269:81-84.

Kumar TR, Palapattu G, Wang P, Woodruff TK, Boime I, Byrne MC, Matzuk MM (1999) Transgenic models to study gonadotropin function: the role of folliclestimulating hormone in gonadal growth and tumorigenesis. Molecular Endocrinology 13:851-865.

Kumar TR, Wang Y, Lu N, Matzuk MM (1997) Follicle stimulating hormone is required for ovarian follicle maturation but not male fertility. Nat Genet 15: 201-204.

La Spada AR, Wilson EM, Lubahn DB, Harding AE,
Fischbeck KH (1991) Androgen receptor gene mutations in X-linked spinal and bulbar muscular atrophy. Nature 352:77-79.

Laue L, Chan WY, Hsueh AJ, Kudo M, Hsu SY, Wu SM, Blomberg L, Cutler GB, Jr (1995) Genetic heterogeneity of constitutively activating mutations of the human luteinizing hormone receptor in familial male limited precocious puberty. Proc Nat'l Acad Sci USA 92:1906-1910.

Layman LC, Cohen DP, Jin M, Xie J, Li Z, Reindollar RH, Bolbolan S, Bick DP, Sherins RR, Duck LW, Musgrove LC, Sellers JC, Neill JD (1998) Mutations in gonadotropin-releasing hormone receptor gene cause hypogonadotropic hypogonadism. Nat Genet 18:14-15. Layman LC, Lee EJ, Peak DB, Namnoum AB, Vu KV, van Lingen BL, Gray MR, McDonough PG, Reindollar RH, Jameson JL (1997) Delayed puberty and hypogonadism caused by mutations in the follicle-stimulating hormone beta-subunit gene. N Engl J Med 337:607611.

Leanos-Miranda A, Janovick JA, Conn PM (2002) Receptormisrouting: an unexpectedly prevalent and rescuable etiology in gonadotropin-releasing hormone receptormediated hypogonadotropic hypogonadism. J Clin Endocrinol Metab 87:4825-4828.

Legouis R, Hardelin JP, Levilliers J, Claverie JM, Compain S, Wunderle V, Millasseau P, Le Paslier D, Cohen D, Caterina D, Bougueleret L, Delemarre-Van de Waal H, Lutfalla G, Weissenbach J, Petit C, (1991) The candidate gene for the X-linked Kallmann syndrome encodes a protein related to adhesion molecules. Cell 67:423-435.

Lei ZM, Mishra S, Zou W, Xu B, Foltz M, Li X, Rao CV (2001) Targeted disruption of luteinizing hormone/ human chorionic gonadotropin receptor gene. Mol Endocrinol 15:184-200.

Ligtenberg MJ, Siers M, Themmen AP, Hanselaar TG, Willemsen W, Brunner HG (1999) Analysis of mutations in genes of the follicle stimulating hormone receptor 
signaling pathway in ovarian granulosa cell tumors. J Clin Endocrinol Metab 84:2233-2234.

Lim J, Ghadessy FJ, Abdullah AAR, Pinsky L, Trifiro M, Yong EL (2000) Human androgen receptor mutation disrupts ternary interactions between ligand, receptor domains, and the coactivator TIF2 (transcription intermediary factor). Mol Endocrinol 14:1187-1197.

Lindstedt G, Nyström E, Matthews C, Ernest I, Janson PO, Chatterjee K (1998) Follitropin (FSH) deficiency in an infertile male due to FSHbeta gene mutation. A syndrome of normal puberty and virilization but underdeveloped testicles with azoospermia, low FSH but high lutropin and normal serum testosterone concentrations. Clin Chem Lab Med 36:663-665.

Liu G, Duranteau L, Carel J-C, Monroe J, Doyle DA, Shenker A (1999) Leydig-cell tumors caused by an activating mutation of the gene encoding the luteinizing hormone receptor. N Engl J Med 341:1731-1736.

Lyon MF, Hawkes SG (1970) X-linked gene for testicular feminization in the mouse. Nature 227:1217-1219.

Ma X, Dong Y, Matzuk MM, Kumar TR (2004) Targeted disruption of luteinizing hormone beta-subunit leads to hypogonadism, defects in gonadal steroidogenesis, and infertility. Proc Natl Acad Sci USA 101:1729417299.

Marshall JC, Kelch RP (1986) Gonadotropin-releasing hormone: role of pulsatile secretion in the regulation of reproduction. N Engl J Med 315:1459-1468.

Martens JWM, Verhoef-Post M, Abelin N, Ezabella M, Toledo SPA, Brunner HG, Themmen APN (1998) A homozygous mutation in the luteinizing hormone receptor causes partial Leydig cell hypoplasia: Correlation between receptor activity and phenotype. Molecular Endocrinol 12:775-784.

Mason AJ, Hayflick JS, Zoeller RT, Young WS III, Phillips HS, Nikolics K, Seeburg PH (1986a) A deletion truncating the gonadotropin-releasing hormone gene is responsible for hypogonadism in the hpg mouse. Science 234:1366-1371.
Mason AJ, Pitts SL, Nikolics K, Szonyi E, Wilcox JN, Seeburg PH, Stewart TA (1986b) The hypogonadal mouse: reproductive functions restored by gene therapy. Science 234:1372-1378.

Matsumoto T, Takeyama K, Sato T, Kato S (2003) Androgen receptor functions from reverse genetic models. J Steroid Biochem Mol Biol 85:95-99.

Matthews C, Chatterjee VK (1997) Isolated deficiency of follicle stimulating hormone re-revisited. N Engl J Med 337:642.

Matthews $\mathrm{CH}$, Borgato S, Beck-Peccoz P, Adams M, Tone Y, Gambino G, Casagrande S, Tedeschini G, Benedetti A, Chatterjee VK (1993) Primary amenorrhoea and infertility due to a mutation in the beta-subunit of follicle-stimulating hormone. Nature Genetics 5: 83-86.

McPhaul MJ (1999) Molecular defects of the androgen receptor. J Steroid Biochem Mol Biol 69:315-322.

Miura K, Acierno JS Jr, Seminara SB (2004) Characterization of the human nasal embryonic LHRH factor gene, NELF, and a mutation screening among 65 patients with idiopathic hypogonadotropic hypogonadism (IHH). J Hum Genet 49:265-268.

Nilsson C, Jiang M, Pettersson K, Iitiä A, Mäkelä M, Simonsen H, Easteal S, Herrera RJ, Huhtaniemi I (1998) Determination of a common genetic variant of luteinizing hormone using DNA hybridization and immunoassays. Clin Endocrinol (Oxford) 49: 369-376.

Nishimura R, Shin J, Ji I, Middaugh CR, Kruggel W, Lewis RV, Ji TH (1986) A single amino acid substitution in an ectopic alpha subunit of a human carcinoma choriogonadotropin. J Biol Chem 261: 10475-10477.

Okuda K, Yamada T, Imoto H, Komatsubara H, Sugimoto O (1994) Antigenic alteration of an anomalous human luteinizing hormone caused by two chorionic gonadotropin-type amino-acid substitutions. Biochem Biophys Res Comm 200:584-590. 
Petaja-Repo UE, Hogue M, Laperriere A, Bhalla S, Walker P, Bouvier M (2001) Newly synthesized human delta opioid receptors retained in the endoplasmic reticulum are retrotranslocated to the cytosol, deglycosylated, ubiquitinated, and degraded by the proteasome. J Biol Chem 276:4416-4423.

Pettersson K, Mäkelä MM, Dahlén P, Lamminen T, Huoponen K, Huhtaniemi I (1994) Genetic polymorphism found in the LH beta gene of an immunologically anomalous variant of human luteinizing hormone. Europ J Endocrinol 130(Suppl) 2:65.

Phillip M, Arbelle JE, Segev Y, Parvari R (1998) Male hypogonadism due to a mutation in the gene for the beta-subunit of follicle-stimulating hormone. N Engl J Med 338:1729-1732.

Quigley CA, De Bellis A, Marschke KB, el-Awady MK, Wilson EM, French FS (1995) Androgen receptor defects: historical, clinical, and molecular perspectives. Endocr Rev 16:271-321.

Raivio T, Falardeau J, Dwyer A, Quinton R, Hayes FJ, Hughes VA, Cole LW, Pearce SH, Lee H, Boepple P, Crowley WF Jr, Pitteloud N (2007) Reversal of idiopathic hypogonadotropic hypogonadism. N Engl J Med 357:863-873.

Rao CV (1996) The beginning of a new era in reproductive biology and medicine: expression of low levels of functional luteinizing hormone/human chorionic gonadotropin receptors in non-gonadal tissues. J Physiol Pharmacol 47(Suppl) 1:41-53.

Risma KA, Clay CM, Nett TM, Wagner T, Yun J, Nilson JH (1995) Targeted overexpression of luteinizing hormone in transgenic mice leads to infertility, polycystic ovaries, and ovarian tumors. Proc Natl Acad Sci USA 92:1322-1326.

Romero Y, Meikar O, Papaioannou MD, Conne B, Grey C, Weier M, Pralong F, De Massy B, Kaessmann H, Vassalli J-D, Kotaja N, Nef S (2011) Dicer1 depletion in male germ cells leads to infertility due to cumulative meiotic and spermiogenic defects.
PLoS ONE 6:e25241.

Sar M, Lubahn DB, French FS, Wilson EM (1990) Immunohistochemical localization of the androgen receptor in rat and human tissues. Endocrinology 127:3180-3186.

Schubert U, Anton LC, Gibbs J, Norbury CC, Yewdell JW, Bennink JR (2000) Rapid degradation of a large fraction of newly synthesized proteins by proteasomes. Nature 404:770-774.

Seminara SB, Messager S, Chatzidaki EE, Thresher RR, Acierno JS Jr, Shagoury JK, Bo-Abbas Y, Kuohung W, Schwinof KM, Hendrick AG, Zahn D, Dixon J, Kaiser UB, Slaugenhaupt SA, Gusella JF, O'Rahilly S, Carlton MB, Crowley WF Jr, Aparicio SA, Colledge WH (2003) The GPR54 gene as a regulator of puberty. N Engl J Med 349:1614-1627. Semple RK, Topaloglu AK (2010) The recent genetics of hypogonadotropic hypogonadism-novel insights and new questions. Clin Endcorniol (Oxford) 72: 427-435.

Shenker A, Laue L, Kosugi S, Merendino JJ, Jr, Minegishi T, Cutler GB Jr (1993) A constitutively activating mutation of the luteinizing hormone receptor in familial male precocious puberty. Nature 365:652-654.

Simoni M, Gromoll J, Höppner W, Kamischke A, Krafft T, Stahle D, Nieschlag E (1999) Mutational analysis of the follicle-stimulating hormone (FSH) receptor in normal and infertile men: identification and characterization of two discrete FSH receptor isoforms. J Clin Endocrinol Metab 84:751-755.

Simoni M, Gromoll J, Nieschlag E (1997) The folliclestimulating hormone receptor: biochemistry, molecular biology, physiology, and pathophysiology. Endocrine Rev 18:739-773.

Singh J, Handelsman DJ (1996) The effects of recombinant FSH on testosterone-induced spermatogenesis in gonadotrophin-deficient (hpg) mice. J Androl 17:382393.

Tapanainen JS, Aittomäki K, Min J, Vaskivuo T, 
Huhtaniemi IT (1997) Men homozygous for an inactivating mutation of the follicle-stimulating hormone (FSH) receptor gene present variable suppression of spermatogenesis and fertility. Nature Genetics 15:205206.

Themmen APN, Huhtaniemi IT (2000) Mutations of gonadotropins and gonadotropin receptors: elucidating the physiology and pathophysiology of pituitarygonadal function. Endocr Rev 21:551-583.

Topaloglu AK, Lu ZL, Farooqi IS, Mungan NO, Yuksel B, O'Rahilly S, Millar RP (2006) Molecular genetic analysis of normosmic hypogonadotropic hypogonadism in a Turkish population: identification and detailed functional characterization of a novel mutation in the gonadotropin-releasing hormone receptor gene. Neuroendocrinolgy 84:301-308.

Tsutsumi R, Webster NJ (2009) GnRH pulsatility, the pituitary response and reproductive dysfunction. Endocr J 56:729-737.

Vornberger W, Prins G, Musto NA, Suarez-Quian CA (1994) Androgen receptor distribution in rat testis: new implications for androgen regulation of spermatogenesis. Endocrinology 134:2307-2316.

Wang Q, Ghadessy FJ, Trounson A, de Kretser D, McLachlan R, Ng SC, Yong EL (1998) Azoospermia associated with a mutation in the ligand binding domain of an androgen receptor displaying normal ligand binding, but defective transactivation. J Clin Endocrinol Metab 83:4303-4309.

Wang R-S, Yeh S, Tzeng C-R, Chang C (2009) Androgen receptor roles in spermatogenesis and fertility: lessons from testicular cell-specific androgen receptor knockout mice. Endocr Rev 30:119-132.
Weiss J, Axelrod L, Whitcomb RW, Harris PE, Crowley WF, Jameson JL (1992) Hypogonadism caused by a single amino acid substitution in the beta subunit of luteinizing hormone. N Engl J Med 326:179-183. Wintermantel TM, Campbell RE, Porteous R, Bock D, Grone HJ, Todman MG, Korach KS, Greiner E, Perez CA, Schutz G, Herbison AE (2006) Definition of estrogen receptor pathway critical for estrogen positive feedback to gonadotropin-releasing hormone neurons and fertility. Neuron 52:271-280.

Wolczynski S, Laudanski P, Jarzabek K, Mittre H, Lagarde JP, Kottler ML (2003) A case of complete hypogonadotropic hypogonadism with a mutation in the gonadotropin-releasing hormone receptor gene. Fertil Steril 79:442-444.

Yeh S, Tsai MY, Xu Q, Mu XM, Lardy H, Huang KE, Lin $\mathrm{H}$, Yeh SD, Altuwaijri S, Zhou X, Xing L, Boyce BF, Hung MC, Zhang S, Gan L, Chang C (2002) Generation and characterization of androgen receptor knockout (ARKO) mice: an in vivo model for the study of androgen functions in selective tissues. Proc Natl Acad Sci USA 99:13498-13503.

Yong EL, Ng SC, Roy AC, Yun G, Ratnam SS (1994) Pregnancy after hormonal correction of severe spermatogenic defect due to mutation in androgen receptor gene. Lancet 344:826-827.

Zhang FP, Poutanen M, Wilbertz J, Huhtaniemi I (2001) Normal prenatal but arrested postnatal sexual development of luteinizing hormone receptor knockout (LuRKO) mice. Mol Endocrinol 15:172-183.

(Received 4 November 2012, Received in revised form 1 December 2012, Accepted 10 December 2012) 